AGATA MIĘTEK

Wydział Prawa i Administracji UMK

\title{
Nowa teoria prawa naturalnego. Główne konteksty i problemy
}

U podstaw niekwestionowanego rozkwitu doktryn prawa naturalnego, które po latach zapomnienia ponownie odgrywają rudymentarną rolę w jurysprudencji, leżą dwie zasadnicze przyczyny. Pierwszą z nich jest niewątpliwie spór między pozytywizmem prawniczym a zwolennikami prawa naturalnego, którego siłę podsyciło doświadczenie II wojny światowej i Holokaustu. Drugi powód ma związek z przemianami cywilizacyjnymi następującymi w świecie. Przez dość długi czas prawo naturalne pozostawało po prostu elementem katolickiej nauki społecznej i było ściśle związane z doktryną chrześcijańską, jednak równolegle do wzrostu zainteresowania kwestiami wymagającymi ważkiej refleksji moralnej, takimi jak aborcja czy eutanazja, zanotować należy ponowny rozkwit doktryn prawnonaturalnych. Bez wątpienia wpływ na taki stan rzeczy ma niedoskonałość, powszechnego w demokratycznych społeczeństwach, dyskursu liberalnego. Jak wskazuje Michael Sandel, liberalne społeczeństwa nie potrafią odnaleźć odpowiedzi na pytania natury moralnej, z którymi w obliczu rozwoju technologicznego zmaga się współczesny człowiek. Język autonomii, bezstronności czy praw indywidualnych okazuje się bezużyteczny i pozostawia człowieka osamotnionego wobec wyzwań niesionych przez cywilizację. ${ }^{1}$ W literaturze sekundarnej podejmuje się próbę podziału poglądów naturalnoprawnych właśnie w odniesieniu do wymienionych przyczyn, gdzie po jednej stronie stawia się na przykład Johna Finnisa, jako kontynuatora tradycji wywodzącej się od

M. Sandel, The Case against Perfection: Ethics in the Age of Genetic Engineering, London 2007, s. 9. 
Arystotelesa i św. Tomasza; po drugiej zaś - Lona L. Fullera i tych, których twórczość skupia się w zasadniczej części na dyskusji z pozytywizmem prawniczym².

Nowa teoria prawa naturalnego (New Natural Law Theory - NNLT) to tylko jeden z wielu nurtów związanych z doktryną prawa naturalnego we współczesnej filozofii prawa i wyróżniają go co najmniej dwie cechy. Po pierwsze, nie jest to tylko kontynuacja jakiegoś istniejącego prądu intelektualnego. Pomimo bowiem licznych odwołań do św. Tomasza i Arystotelesa, tomiści odsądzają od czci i wiary przedstawicieli NNLT. Po wtóre, nowa teoria prawa naturalnego jest przykładem od dawna już niespotykanej w humanistyce szkoły. Jej przedstawiciele wspólnie propagują swoje poglądy, angażują się w liczne projekty społeczne i wzajemnie wspierają w rozlicznych dyskusjach $z$ adwersarzami. Jest to więc nurt zwarty i jako taki nie przypomina w niczym na przykład komunitarystów, z których każdy jest autorem odrębnych, nierzadko odległych od reszty, poglądów.

Za początek nowej teorii prawa naturalnego uznaje się opublikowany w 1965 roku artykuł Germaina Griseza, będący komentarzem do artykułu 2, kwestii 94 Summy teologicznej św. Tomasza ${ }^{3}$. W tekście tym Grisez odnosi się krytycznie do sposobu, w jaki powszechnie rozumiana była pierwsza zasada praktycznego rozumu sformułowana przez Akwinatę. Dotychczas bowiem w klasycznej tradycji tomistycznej zasada Bonum est faciendum et prosequendum, et malum vitandum była rozumiana jako nakaz, by czynić dobro i unikać zła. Grisez natomiast wskazuje, iż winna ona brzmieć raczej tak: dobro ma być czynione i należy do niego dążyć, zło zaś jest tym, czego należy unikać. Różnica między tymi dwiema interpretacjami polega na tym, że u Griseza nie chodzi o jakiś nakaz moralny czy przesłankę, z której wyprowadzić można inne normy, ale o taką podstawę rozumowania praktycznego, która pozwala unikać sytuacji, w której następuje utracenie celu rozumowania - bezcelowość (pointlessness) ${ }^{4}$. Natomiast najbardziej systematyczny wykład koncepcji prawa naturalnego reprezentatywnej dla NNLT dał w swym opus magnum John Finnis. Tak on, jak i Grisez niemal natychmiast spotkali się z krytyką. Kilka lat później (w 1987 roku) obaj wspólnie z Josephem Boylem opublikowali artykuł dokonujący pewnej korekty teorii i będący jednocze-

D. M. Patterson, A Companion to Philosophy of Law and Legal Theory, New York 1996, s. $230-231$.

G. Grisez, The First Principle of Practical Reason. A commentary on the „Summa Theologiae”, 1-2, Question 94, Article 2, „Natural Law Forum”, nr 10, 1965, s. 168-201.

4 P. Łabieniec, Prawo rozumu. O teorii prawa naturalnego Johna Finnisa, Łódź 2004, s. 11-13. 
śnie ustosunkowaniem się do zarzutów, z jakimi musiała się zmierzyć NNLT ${ }^{5}$. Oprócz wyżej wymienionych, do przedstawicieli szkoły należy zaliczyć także Roberta P. George'a, który jest autorem rozlicznych książek i artykułów przybliżających i, najczęściej, broniących owej teorii w dyskusji z jej adwersarzami.

Gdzie przebiega dystynkcja między nurtem, który został nazwany nową teorią prawa naturalnego a teorią „starą”? Russel Hittinger, który w książce A Critique of the New Natural Law ${ }^{6}$ systematyzuje krytykę skierowaną przeciwko NNLT i, dodając przy tym kilka własnych uwag, wskazuje na dwa osiowe zagadnienia organizujące to rozróżnienie. Primo, hierarchiczna struktura dóbr była ślepym zaułkiem dotychczasowych teorii prawnonaturalnych, jednak poprawne określenie owej hierarchii było jednocześnie warunkiem sine qua non prawidłowej ewaluacji czynów. W miejsce owej systematyczności NNLT wprowadza wiele nieredukowalnych dóbr podstawowych, które nie pozostają ze sobą w relacjach nadrzędności-podrzędności, tym samym dla oceny jakiegoś aktu niezbędne jest zawsze uznanie każdego spośród owych dóbr. Drugiej zasadniczej różnicy upatruje Hittinger w znaczeniu metafizyki i antropologii filozoficznej dla obydwu teorii. Wersja klasyczna prawa naturalnego uznawała te dwie dyscypliny za rudymentarne - ich status wynikał z tego, iż są one niezbędne dla prawidłowego określenia natury najwyższego dobra, a tym samym dla skonstruowania ich poprawnej hierarchii. Natomiast nowa doktryna odrzuca eudaimonię jako dobro najistotniejsze, by w ten sposób zanegować znaczenie metafizyki i antropologii filozoficznej przesłanką prawa naturalnego nie jest tu, jak było to $w$ tradycyjnych doktrynach, żadna metafizyczna bądź antropologiczna teza o naturze ludzkiej, lecz rozum praktyczny ${ }^{7}$. Różnice wskazywane przez Hittingera są jednocześnie podstawą, na której buduje on swoją krytykę NNLT. Stwierdza on, iż nowa teoria tak bardzo różni się od swych poprzedniczek, iż być może nie zasługuje w ogóle na bycie określaną mianem doktryny prawa naturalnego. Trzeba też przyznać, iż nierzadko wskazuje się także na to, że odejście nowej teorii od metafizyki I - co być może ważniejsze - teologii jest rodzajem jej wykorzenienia z tradycji moralnej, na której wyrosła, choć należy też skonstatować, iż jest jasne, że owo metafizyczne i teologiczne prawo naturalne nie

J. Finnis, G. Grisez, J. Boyle, Practical Principles, Moral Truth, and Ultimate Ends, „The American Journal of Jurisprudence", vol. 32, 1987, s. 32.

R. Hittinger, A Critique of the New Natural Law Theory, Notre Dame 1987.

K. Staley, New Natural Law, Old Natural Law, or the Same Natural Law?, „The American Journal of Jurisprudence", vol. 38, 1993, s. 109-110. 
miało szans stania się podstawą dla powszechnie podzielanej etyki politycz$n \mathrm{j}^{8}$.

Obok dwóch zasadniczych kwestii wskazanych przez Hittingera należy także odnieść się do jeszcze jednego zagadnienia konstytutywnego dla nurtu nazwanego nową teorią prawa naturalnego - chodzi o stosunek do tzw. błędu naturalistycznego, tzn. relacji między bytem a powinnością. Jest to problem, na którego istnienie wskazał David Hume, podniesiony ponownie przez G. E. Moore'a, od czasu którego zagadnienie to stało się ponownie jednym z ważniejszych we współczesnej filozofii. Przedstawiciele NNLT punktem wyjścia swojej koncepcji nie czynią jakichkolwiek zdań dotyczących ludzkiej natury czy Boga, z których potem wyprowadziliby różnego rodzaju nakazy. W tekście Practical Principles, Moral Truths, and Ultimate Ends Finnis, Grisez i Boyle piszą: „Teoria, której bronimy odchodzi od modelu klasycznego - przynajmniej w jego potocznym rozumieniu - przez zwrócenie całej uwagi na fakt, iż moralna powinność nie może zostać wywiedziona z jest prawdy teoretycznej, na przykład metafizycznej czy antropologicznofilozoficznej". NNLT punktem wyjścia całej teorii uczyniła nie fakty dotyczące natury ludzkiej, ale podstawowe wartości, które mają charakter oczywisty - tą drogą starając się ominąć pułapkę błędu naturalistycznego i nie wyciągając wniosków na temat powinności z faktów dotyczących natury ludzkiej ${ }^{10}$. Stosunek bytu i powinności wydaje się być jednym z tych kilku punktów (o ile nie najistotniejszym), który z jednej strony odróżnia nową teorię od swych poprzedniczek, ale także przeciwko któremu skierowane jest ostrze krytyki kontestatorów NNLT ${ }^{11}$.

\section{Główne wątki krytyczne wobec nowej teorii prawa naturalnego}

Przedstawiciele nowej teorii prawa naturalnego spotykają się z rozlicznymi uwagami kierowanymi pod ich adresem nie tylko ze strony tych, którzy nie podzielają tradycji prawnonaturalnej, ale także ze strony na przykład tomistów, z którymi przecież łączy nową teorię cały poczet antenatów. Należy też podkreślić różnorodność zarzutów kierowanych pod adresem NNLT - odnoszą się one bowiem praktycznie do wszystkich najważniejszych kwestii poruszanych przez autorów wiązanych ze szkołą, a posunięte są tak daleko, że zdarza się, iż nowej teorii odmawia się zupełnie prawa nazywania

\footnotetext{
R. Plant, Politics, Theology and History, Cambridge 2001, s. 159.

J. Finnis, G. Grisez, J. Boyle, dz. cyt., s. 101-102.

H. Kainz, Natural Law: An Introduction and Re-examination, La Salle, 2004, s. 46.

J. Koterski, On the Natural Law Theory, „Modern Age”, vol. 42, no. 4, Fall 2000, s. 415-418.
} 
się doktryną prawa naturalnego - dzieje się tak choćby z powodu stosunku np. Finnisa do prawa pozytywnego, czy też ze względu na konstrukcję teoretyczną przyjętą przez niego dla uniknięcia błędu naturalistycznego ${ }^{12}$. Zdarza się także, iż nowa teoria prawa naturalnego określana jest, niezbyt sympatycznie, jako po prostu ochrzczona wersja kantyzmu (babtized Kantianism) ${ }^{13}$.

Zacząć wypada od wspomnianego już Russela Hittingera. Przytoczono tu linię demarkacyjną oddzielającą, zdaniem Hittingera, nową i starą teorię prawa naturalnego. Zasadnicza część jego krytyki jest ściśle powiązana z podstawami tego rozróżnienia. Autor negatywnie ocenia bowiem rolę, jaką w nowej teorii odgrywa religia. Jego zdaniem istnieje zasadnicza logiczna dwuznaczność odnosząca się do religii jako jednej z podstawowych form dobra, jak widzą ją przedstawiciele NNLT, co w konsekwencji prowadzi do kolejnych problemów związanych na przykład z koncepcją praktycznego rozumu, relacją między rozumem a objawieniem, naturą a transcendencją. Hittinger stawia cały szereg podobnych pytań, na które jego zdaniem nowa teoria prawa naturalnego nie jest $\mathrm{w}$ stanie udzielić spójnych odpowiedzi ${ }^{14}$.

Z kolejną istotną krytyką spotkała się nowa teoria prawa naturalnego ze strony Jean Porter, która obok argumentów wymierzonych na przykład $\mathrm{w}$ proporcjonalizm, podnosi także dwie zupełnie odmienne kwestie. Uważa więc, że NNLT nie wysuwa żadnej racjonalnej argumentacji odnoszącej się do oczywistości dóbr podstawowych. Oczywistość podstawowych zasad, oznacza, iż są one per se nota - zrozumiałe przez sam fakt zrozumienia znaczenia wyrażających je terminów ${ }^{15}$. Owa oczywistość nie jest jednak, zdaniem Porter, poparta jakimkolwiek sensownym wyjaśnieniem. Druga zaś kwestia jest bezpośrednio powiązana z tym zarzutem. Porter uważa, iż nowa teoria prawa naturalnego nie jest w stanie dać żadnych zadowalających wyjaśnień w teorii moralności. Jej zdaniem dzieje się tak z dwóch przyczyn: nadmierna hipostaza dóbr podstawowych oddziela je w znacznym stopniu od człowieka, a to natomiast sprawia, że przedstawiciele NNLT ustawiają siebie $\mathrm{w}$, jak to określa Porter, „wysoce nieprawdopodobnych” czy też „fantastycznych” pozycjach moralnych. $\mathrm{Z}$ wszystkich tych względów zaś nowa teoria prawa naturalnego nie może być pomocna człowiekowi w podejmowaniu przez niego najważniejszych wyborów moralnych ${ }^{16}$.

12 R. P. George, G. Bradley, The New Natural Law Theory: A Reply to Jean Porter, „The American Journal of Jurisprudence", vol. 39, 1994, s. 303.

Ch. Wolfe, Natural Law Liberalism, New York 2006, s. 171

R. Miller, Review: Untitled, „The Journal of Religion”, vol. 70, no. 1, 1990, s. 125.

J. Finnis, G. Grisez, J. Boyle, dz. cyt., s. 106.

16 J. Porter, Basic Goods and the Human Good in Recent Catholic Moral Theology, "The Thomist”, no. 47, 1993, cyt. za: R. P. George i G. V. Bradley, The New Natural..., s. 303-315. 
Kolejną godną przytoczenia krytyką jest ta przedstawiona przez Jeffrey'a Goldsworthy'a w artykule Fact and Value in the New Natural Law Theory. Twierdzi on, że nowa teoria prawa naturalnego tak naprawdę wciąż uwikłana jest $\mathrm{w}$ spór z neoscholastykami - jej przedstawiciele nie tylko przytaczają swą własną argumentację przeciwko zarzutowi Hume’a odnoszącemu się do wyprowadzania powinności z bytu, ale starają się także udowodnić, że całość sporu wynika z tego, że zarówno oponenci jak i zwolennicy św. Tomasza nie zrozumieli w sposób prawidłowy jego poglądów. Jak wiadomo scholastycy uznaliby, iż poddanie się argumentom Hume’a byłoby po prostu opuszczeniem stanowiska na rzecz subiektywizmu. Co więcej, jak wskazuje Goldsworthy, można też wysunąć wobec NNLT cały szereg obiekcji z pozycji niekognitywistycznych - skoro normy nie są wywodzone z faktów, to ich źródłem muszą być projekcje ludzkich uczuć i pożądań ${ }^{17}$. I tak, jak zauważa Goldsworthy, kognitywistyczne stanowisko NNLT wpływające na obiektywizm dóbr podstawowych a także motywacyjna siła nieinstrumentalnych powodów działania muszą upaść z jednego z dwóch powodów. Albo dlatego, że w ten sposób NNLT staje się nieodróżnialna od stanowiska niekognitywistycznego, gdzie moralność jest zawsze subiektywistyczna, a rozum praktyczny instrumentalny. Albo z powodu tego, że poddaje się w ten sposób nieco innej formule tego, co John Mackie nazwał argumentem z dziwaczności (argument from "queerness" $\left.{ }^{\prime 18}\right)^{19}$.

Christopher Wolfe, w przytaczanej powyżej książce, wskazuje na jeszcze jedną grupę zarzutów kierowanych pod adresem nowej teorii prawa naturalnego - chodzi o argumentację przytaczaną przede wszystkim przez Ralpha McInerny'a. Jego argumenty wynikają z założenia podzielanego przez myślicieli związanych z NNLT, będącego efektem wielokrotnie już tu przytaczanej próby przełamania związku między bytem i powinnością. Chodzi o wyraźne oddzielenie rozumu praktycznego od teoretycznego. Proces rozumowania praktycznego posługuje się pojęciem oczywistych dóbr podsta-

17 J. Goldsworthy, Fact and Value in the New Natural Law Theory, „The American Journal of Jurisprudence", vol. 41, 1996, s. 21-22.

18 Jest to argument, który został użyty po raz pierwszy przez Mackiego w wydanej w 1977 roku książce Ethics: Inventing Right and Wrong, składają się na niego dwa elementy: metafizyczny i epistemologiczny. Pierwszy wyraża się w tezie, iż jeśli istniałyby obiektywne wartości, byłyby one istotami, jakościami czy relacjami niezwykle dziwacznego rodzaju, kompletnie różnego od wszystkiego innego we wszechświecie. Element drugi to twierdzenie, że wiedza o obiektywnych moralnych wartościach wymagałaby posiadania specjalnych umiejętności moralnej percepcji lub intuicji, kompletnie różnych od tych używanych do poznawania wszystkiego innego - M. Baghramian, Relativism, London-New York 2004, s. 284.

19 R. P. George, A Defense of the New Natural Law Theory, "The American Journal of Jurisprudence", vol. 41, 1996, s. 47. 
wowych. Skoro więc istnieje „dobro”, argumentuje McInerny, to znaczy, że istnieje też jakiś rodzaj „lepszości” istoty, dla której jest ono dobrem; skoro zaś tak, to istnieje także pewien wymagany rodzaj wiedzy, obecnej choćby jedynie implicite, ale będącej zawsze wiedzą z zakresu rozumności teoretycznej. W ten sposób, wskazuje McInerny, następuje przemieszanie dwóch porządków, z których odrębności nowa teoria prawa naturalnego uczyniła jeden ze swych największych atutów ${ }^{20}$.

Już ten krótki przegląd stanowisk krytycznych wobec nowej teorii prawa naturalnego pozwala stwierdzić, iż swym artykułem, uznawanym za początek nurtu, Germain Grisez, a wraz z nim między innymi Finnis czy George, wyraźnie rozbudzili rzeszę oponentów. Jednocześnie jednak z wielką siłą przypomnieli teorii prawa tradycję naturalnoprawną, jako przydatną do innych kwestii niż tylko do rozważań dotyczących obowiązywania prawa niesprawiedliwego. 


\section{The new natural law theory. Main contexts and problems.}

The new natural law theory (NNLT) is one of the most important contemporary representatives of the natural law tradition. There exist two main reasons for a renewal of the natural law theory. The end of the Second World War and the experience of Holocaust re-established the discussion between legal positivism and natural law. Technology development is the second cause of the revival of the natural law theory.

Russel Huttinger sees two main differences between old and new natural law theories. The first one refers to the hierarchy of goods on the one hand and their incommensurability on the other. The second one is a result of the position of metaphysics and philosophical anthropology in both theories. But there is one more important question that differs those two points of views - the naturalistic fallacy; more precisely: ought-is problem.

The new natural law theory has a lot of opponents. Russel Hittinger criticises the role of the religion in NNLT. Jean Porter reproaches NNLT for two problems: its theory of self-evident basic goods and its uselessness in moral theory. Ralph McInerny criticises new natural law theorists' conception of good - the notion of "good" refers to something "perfective", always requiring some kind of theoretical knowledge.

The new natural law theory is the most significant reformulation of contemporary natural law jurisprudence. 